\title{
Norduz Erkek Kuzularında Testis Özellikleri ve Serum Testosteron Konsantrasyonun Yaşa Göre Değişimi ${ }^{1}$
}

\author{
Ayhan YILMAZ ${ }^{2}$ \\ Firat CENGiZ3
}

Geliş Tarihi: 26.04.2006

\begin{abstract}
Öz: Bu çalışma, Akkaraman varyetesi olarak kabul edilen Norduz erkek kuzularında testis özelliklerinden testis çapı, testis uzunluğu, skrotum çevresi, skrotum uzunluğu, skrotum çevresi/canlı ağırlık oranı, testis hacmi, çift testis ağırlığı, çift epididimis ağırlığı, skrotum ağırlığı ve serum testosteron konsantrasyonunu saptamak amacıyla yapılmıştır. Çalışma materyalini, Yüzüncü Yıl Üniversitesi Ziraat Fakültesi Araştırma ve Uygulama Çiftliği'nde yetiştirilmekte olan Norduz koyunlarının 2003 yılı doğum mevsiminde doğan 32 baş erkek kuzusu oluşturmuştur. Norduz kuzularında testis çapı, testis uzunluğu, skrotum çevresi, skrotum uzunluğu, skrotum çevresi/canlı ağırlık oranı, testis hacmi, çift testis ağırlığı, çift epididimis ağırlığı, skrotum ağırlığı ve serum testosteron konsantrasyonuna ilişkin incelenen özelliklere ait en küçük kareler ortalamaları sırasıyla $4.99 \pm 0.09$ $\mathrm{cm}, 10.47 \pm 0.16 \mathrm{~cm}, 25.51 \pm 0.37 \mathrm{~cm}, 16.28 \pm 0.28 \mathrm{~cm}, 0.53 \pm 0.004,324.05 \pm 10.97 \mathrm{~cm}^{3}, 0.319 \pm 0.02 \mathrm{~g}, 0.051 \pm 0.006$ $\mathrm{g}, 0.223 \pm 0.02 \mathrm{~g}$ ve $2.42 \pm 0.12 \mathrm{ng} / \mathrm{ml}$ olarak bulunmuştur. Çalışmada testis özellikleri ve serum testosteron konsantrasyonu üzerine incelenen çevre faktörlerinin etkileri yaş dönemleri ve canlı ağırlık dışında üreme özelliğine göre değiştiği gözlenmiştir.
\end{abstract}

Anahtar Kelimeler: Erkek kuzu, Norduz, testis özellikleri, testosteron konsantrasyonu

\section{Change in Age Testis Characteristics and Serume Testosterone Concentration Based on in Norduz Male Lambs}

\begin{abstract}
This study was aimed to detect the testis diameter, testis length, scrotum circumference, scrotum length, testis volume, scrotum circumference/live weight ratio from testis characteristics and testosterone concentration in Norduz (variety of Akkaraman) male lambs. The experiment was carried out on 32 male lambs born in the birth season of 2003 at Agricultural Research Center of University of Yüzüncü Yll. The least squares means for testis diameter, testis length, scrotum circumference, scrotum length, scrotum circumference/live weight ration, testis volume and testosterone concentration in male lambs were found as $4.99 \pm 0.09 \mathrm{~cm}, 10.47 \pm 0.16 \mathrm{~cm}, 25.51 \pm 0.37 \mathrm{~cm}, 16.28 \pm 0.28 \mathrm{~cm}, 0.53 \pm 0.004,324.05 \pm 10.97 \mathrm{~cm}^{3}, 0.319 \pm 0.02 \mathrm{~kg}$, $0.051 \pm 0.006 \mathrm{~kg}, 0.223 \pm 0.02 \mathrm{~kg}$ and $2.42 \mathrm{ng} \mathrm{ml}^{-1}$, respectively. In this study, effect of the environmental factors on testis characteristics and testosterone concentration except for daily age and live weight were different based on reproduction characteristics.
\end{abstract}

Key Words: Male lambs, Norduz, testis characteristics, testosterone concentration

\section{Giriş}

Testis özellikleri kolayca ve erken yaşta ölçülebilmesi, kalıtım derecesinin yüksekliği ve dişi akrabalarının yumurta sayısıyla arasında yüksek düzeyde ilişkinin varlığı gibi nedenlerle döl veriminin genetik ıslahında üzerinde durulan özelliklerden bir olmuştur. Erkek kuzularda testis gelişimi hem erkeğin hem de dişi akrabalarının üreme kabiliyetini iyileştirmede önemli bir seleksiyon ölçütüdür (Kaymakçı ve ark. 1988, Toe ve ark. 2000). Aynı şekilde serum ya da plazma testosteron, FSH ve LH konsantrasyonları ya tek başlarına ya da diğer üreme özellikleriyle birlikte koçların üreme gücünün tanımlanmasında önemlidir (Lincoln ve ark. 1990,
Langford ve ark. 1998, Aygün ve Karaca, 2000). Koçlarda söz konusu hormonların serum ya da plazma konsantrasyonları ırk, yaş, besleme ve mevsim gibi faktörlerden etkilenmektedir. Özellikle serum ya da plazma testosteron konsantrasyonu bakımından koçlar arasında gözlenen farklılıkta mevsimin etkisi büyük önem taşımaktadır. $\mathrm{Bu}$ bağlamda mevsimler arasında, mevsim içi aylar, ay içi günler ve gün içinde farklı zamanlarda söz konusu hormonların kan düzeyleri değişmektedir (Lincoln ve ark. 1990; Sanford ve ark. 2000, Fernandez ve ark. 2004).

${ }^{1}$ Bu araştırma doktora tez çalışmasının bir bölümünden hazırlanmıştır. Yüzüncü Yıl Üniv. Bilimsel Projeleri Başkanlığı tarafından 2003-ZF-008 numaralı proje olarak desteklenmiştir.

2. Yüzüncü Yıl Üniv. Ziraat Fak. Zootekni Bölümü - Van

${ }^{3}$. Yüzüncü Yıl Üniv. Ziraat Fak. Zootekni Bölümü - Van 
$\mathrm{Bu}$ çalışmada Norduz erkek kuzularında testis özellikleri ve serum testosteron konsantrasyonun yaş dönemlerine göre değişiminin tanımlanması amaçlanmıştır. Akkaraman ırkının varyetesi olarak kabul edilen Norduz genotipi ile ilgili çok az sayıda araştırma bulunduğundan bu çalışmanın önemli olduğu düşünülmektedir.

\section{Materyal ve Yöntem}

Bu çalışmanın hayvan materyalini Yüzüncü Yıl Üniversitesi Ziraat Fakültesi Zootekni Bölümü Araştırma ve Uygulama Çiftliği'nde yetiştirilmekte olan Norduz koyunlarının 2003 yılı doğum mevsiminde (Mart ayı) doğan 32 baş Norduz erkek kuzusu oluşturmuştur.

Norduz koyunlarının Akkaraman ırkının bir varyetesi olduğu bildirilmektedir (Bingöl 1998). Norduz koyunlarında vücut genel olarak beyaz olmakla birlikte beyazdan sonra kül rengi çoğunlukta olup az miktarda gri- beyaz ve kahverengi-beyaz renklere rastlanmaktadır. Ayrıca, vücudun çeşitli yerlerinde özellikle baş, göğüs ve ayak kısımlarında siyahlıklar bulunmaktadır. Norduz koyunlarında kuyruk üç parça olup, ortadaki parça daha uzundur (Bingöl 1998).

Çalışma materyali olarak kullanılan erkek kuzular, ortalama 3 aylık yaşta sütten kesilmiş ve sütten kesim ağırlıkları saptanmıştır. Erkek kuzularda meralamadan sonra 5-13 ve 13-16 aylık yaş dönemlerinde sırasıyla hayvan başına $400 \mathrm{~g}$ yoğun yem ve $300 \mathrm{~g}$ arpa ik öğünde verilmiştir. Kuru ot olarak ise yonca ve korunga samanı kullanılmıştır. Erkek kuzulara kuru ot serbest olarak verilmiş, sabah ve akşam suları değiştirilmiş ve yemliklerinde sürekli olarak kaya tuzu bulundurulmuştur.

Erkek kuzularda testis özelliklerinin ve canl ağırlığın belirlenmesi çalışmalarına kuzular ortalama 3 aylık yaşta oldukları zaman başlanmış, 16 aylık yaşa kadar aylık denetimler şeklinde devam edilmiş ve toplam 14 ölçüm yapılmıştır. Ölçümlerde testis özelliklerinden testis çapı ve testis uzunluğu metal kumpas, skrotum çevresi ve skrotum uzunluğu ise şeritmetre ile ölçülmüştür (Sönmez ve Kaymakçı, 1987). Testis hacmi $\left(\mathrm{cm}^{3}\right): 0.0396$ x ortalama testis uzunluğu x (Skrotum çevresi) ${ }^{2}$ Godfrey ve ark.'nın (1998) bildirdiği formülden hesaplanmıştır. Çalışma materyali hayvanlar ortalama 16 aylık yaşta kesildikten sonra çift testis ağırığı, çift epididimis ağırlığı ve skrotum ağırlıkları tartılmıştır.

Erkek kuzularda kan örnekleri toplanmasına 3 aylık yaşta başlanmış ve 16 aylık yaşa kadar devam edilmiştir. Kan alımı ayda bir yapılmıştır. Bu amaçla sabah saatlerinde erkek kuzuların boyun toplardamarından (vena jugularis) $10 \mathrm{ml}$ kan alınmıştır. Alınan kanlar 6-7 saat $+4{ }^{\circ} \mathrm{C}$ 'de tutulmuş ve daha sonra 3000 devir/dk 'da 15 dakika santrifüj edilerek serumları ayrılmıştır. Elde edilen serumlardan pastör pipet kullanılarak $5 \mathrm{ml}$ plastik tüplere aktarılmış ve testosteron analizi için $-20{ }^{\circ} \mathrm{C}$ 'de muhafaza edilmiştir. Testosteron analizi RIA (radioimmunoassay) tekniğiyle yapılmıştır. Serum testosteron değerleri analizden önce, normal dağılışa uyum testlerine tabi tutulmuş, normal dağılışa uyum göstermediklerinden dolayı bu verilere karakök transformasyonu uygulanmış ve 1 eklenmiştir.

İstatistiksel analizler: Verilerin değerlendirilmesi Yüzüncü Yıl Üniversitesi Bilgisayar Bilimleri Araştırma ve Uygulama Merkezi'nde bulunan SAS (2005) paket programında En Küçük Kareler analiz yöntemine göre yapılmıştır.

Testis özellikleri, testosteron konsantrasyonu analizinde;

$Y_{i j k l}=\mu+a_{i}+b_{j}+c_{k}+b_{1}\left(x_{i j k l}-\bar{x}\right)+e_{i j k l}$

Çift testis ağırlığı, çift epididimis ağırlığı ve skrotum ağırlığına ilişkin analizde ise;

$Y_{i j k}=\mu+a_{i}+b_{j}+b_{1}\left(x_{i j k}-\bar{x}\right)+e_{i j k}$

Biçiminde iki farklı matematik model kullanılmıştır. Bu modellerde yer alan terimlerden;

$Y_{i j k}=$ kuzunun çift testis ağırlığı, çift epididimis ağırlığı ve skrotum ağırığını,

$Y_{i j k l}=$ kuzunun testis çapı, testis uzunluğu, skrotum çevresi, skrotum uzunluğu, testis hacmi, skrotum çevresi/canlı ağırlık oranı, testosteron konsantrasyonu,

$\mu=$ beklenen populasyon ortalamasını, $a_{i}=i$. ana yaşının etkisini, $b_{i}=j$ doğum tipinin etkisini, $c_{k}=$ $k$. denetimin etkisini, $b_{1}=$ herhangi bir özelliğin canlı ağırlığa $(\mathrm{kg})$ göre regresyonu, $X_{i j k}, X_{i j k l}=$ kuzunun canlı ağırığını (kg), $\bar{x}=$ ortalama canlı ağırlığını (kg), $e_{i j k}, e_{i j k l}=$ normal, bağımsız ve şansa bağlı hatayı göstermektedir.

\section{Bulgular}

Norduz erkek kuzularında testis özellikleri: Norduz erkek kuzularında testis çapı, testis uzunluğu, skrotum çevresi, skrotum uzunluğu, testis hacmi ve skrotum çevresi/canlı ağırlık oranına ilişkin en küçük kareler ortalamaları Çizelge 1'de verilmiştir. Çizelge 1 değerlendirildiğinde söz konusu özelliklere ilişkin değerlerin sırasıyla $4.99 \pm 0.09 \mathrm{~cm} \quad 10.47 \pm 0.16 \mathrm{~cm}$, 

yaşa göre değişimi"

$25.51 \pm 0.37 \mathrm{~cm}, 16.28 \pm 0.28 \mathrm{~cm}, 324.05 \pm 10.97 \mathrm{~cm}^{3} \mathrm{ve}$ $0.53 \pm 0.008$ olduğu görülmektedir. Testis çapı, testis uzunluğu skrotum çevresi, skrotum uzunluğu, testis hacmi ve skrotum çevresi/canlı ağırlık oranı bakımından erkek kuzu yaş dönemleri arasındaki farklılıklar önemlidir $(P<0.05)$.

Testis çapında 270 günlük yaş dönemine kadar artış görülmüş, 330 ile 360 günlük yaş dönemlerinde önemli $(P<0.05)$ bir azalma gözlenmiş ve 390 ile 480 günlük yaş dönemlerinde ise yeniden bir artış görülmüştür. Dört yüz elli ile 480 günlük yaş dönemleri arasında testis çapındaki artış istatistik olarak önemli bulunmamıştır. Testis uzunluğunda 270 günlük yaş dönemine kadar artış gözlenmiş, 300 günlük yaş döneminde ise bir düşüş görülmüştür. Ancak bu düşüş istatistik olarak önemli bulunmamıştır. Daha sonraki yaş dönemlerinde ise testis uzunluğunda yeniden bir artış gözlenmiştir.

Genel olarak, yaş dönemlerine bağlı olarak skrotum çevresinde artış gözlenmiş ancak 240 ile 390 günlük yaş dönemleri arasında skrotum çevresindeki değişim istatistik olarak önemli bulunmamıştır. Skrotum uzunluğunda yaş dönemlerine bağlı olarak artış gözlenmiş ancak 330 ile 390 günlük yaş dönemlerinde önemli $(P<0.05)$ bir düşüş gözlenmiştir.

Testis hacmi üzerine yaş dönemlerinin etkisi önemli $(P<0.05)$ bulunmuştur. Testis hacminin 270 günlük yaş dönemine kadar artış gösterdiği 360 günlük yaş dönemine kadar istatistik olarak değişmediği ve söz konusu yaş döneminden sonra yeniden artmaya başladığı söylenebilir. Skrotum çevresi/canlı ağırlık oranı 270 günlük yaş dönemine kadar artış göstermiş, 390 günlük yaş dönemine kadar istatistik olarak değişmemiş ve daha sonraki yaş dönemlerinde ise yeniden artmaya başlanmıştır. Söz konusu testis özelliklerinin canlı ağırlığa regresyonu önemli bulunmuştur $(\mathrm{P}<0.01)$.

Testis çapı bakımından tekiz kuzular ile ikiz kuzular arasındaki fark ikiz kuzular lehine önemlidir $(P<0.05)$. Testis uzunluğu bakımından doğum tipinin etkisi önemsiz, ana yaşının etkisinin ise önemli $(P<0.05)$ olduğu saptanmıştır. Üç yaşlı anaların kuzularının 4 ve 5 yaşı anaların kuzularından testis uzunluğu bakımından daha üstün olduğu gözlenmiştir.

Skrotum çevresi ve skrotum uzunluğu üzerine doğum tipi ve ana yaşının etkisi istatistik olarak önemli bulunmamıştır. Testis hacmi üzerine doğum tipi ve ana yaşının önemli $(P<0.05)$ etkide bulunduğu gözlenmiştir. Testis hacmi bakımından ikiz kuzuların tekizlere, 3 yaşı anaların kuzularının diğerlerine göre istatistik olarak daha üstün olduğu saptanmıştır. Skrotum çevresi/canlı ağırlık oranı bakımından tekiz ve ikiz kuzular arasında ikiz erkek kuzular lehine $P<0.05$ düzeyinde önemli fark görülmüştür. Ana yaşı grupları arasında ise istatistik olarak önemli bir farklılık bulunmamıştır.

Çizelge 1. Norduz erkek kuzularında bazı testis özellikleri

\begin{tabular}{|c|c|c|c|c|c|c|c|c|}
\hline & & TÇ & TU & SÇ & SU & $\mathrm{TH}$ & & can. ağır. \\
\hline Sınıflama & $\mathrm{n}$ & $\bar{X} \pm S_{\bar{X}}$ & $\bar{X} \pm S_{\bar{X}}$ & $\bar{X} \pm S_{\bar{X}}$ & $\bar{X} \pm S_{\bar{X}}$ & $\overline{\bar{X}} \pm S_{\bar{X}}$ & $\mathrm{n}$ & $\bar{X}_{ \pm} S_{\bar{X}}$ \\
\hline Genel & 417 & $4.99 \pm 0.09$ & $10.47 \pm 0.16$ & $25.51 \pm 0.37$ & $16.28 \pm 0.28$ & $324.05 \pm 10.97$ & 409 & $0.53 \pm 0.008$ \\
\hline \multicolumn{9}{|l|}{ Yaş (gün) } \\
\hline 90 & 32 & $3.28 \pm 0.10^{\mathrm{h}}$ & $7.03 \pm 0.18^{i}$ & $18.16 \pm 0.43^{\text {h }}$ & $12.20 \pm 0.32^{\mathrm{g}}$ & $192.15 \pm 12.66^{h}$ & 32 & $0.41 \pm 0.009^{f}$ \\
\hline 120 & 30 & $3.59 \pm 0.10^{9}$ & $7.37 \pm 0.18^{i}$ & $19.37 \pm 0.42^{9}$ & $13.76 \pm 0.31^{\mathrm{f}}$ & $192.83 \pm 12.35^{\mathrm{h}}$ & 30 & $0.44 \pm 0.009^{e}$ \\
\hline 150 & 32 & $4.21 \pm 0.09^{f}$ & $8.32 \pm 0.16^{h}$ & $21.13 \pm 0.37^{f}$ & $14.09 \pm 0.28^{f}$ & $201.35 \pm 10.98^{h}$ & 32 & $0.46 \pm 0.008^{\mathrm{e}}$ \\
\hline 180 & 30 & $4.74 \pm 0.09^{\mathrm{e}}$ & $9.63 \pm 0.15^{9}$ & $23.96 \pm 0.37^{\mathrm{e}}$ & $15.40 \pm 0.28^{\mathrm{e}}$ & $255.66 \pm 10.86^{9}$ & 30 & $0.52 \pm 0.008^{\mathrm{d}}$ \\
\hline 210 & 30 & $5.15 \pm 0.08^{\text {cd }}$ & $10.20 \pm 0.15^{f}$ & $25.21 \pm 0.35^{d}$ & $15.35 \pm 0.26^{\mathrm{e}}$ & $275.76 \pm 10.23^{9}$ & 30 & $0.54 \pm 0.008^{\mathrm{d}}$ \\
\hline 240 & 30 & $5.51 \pm 0.08^{\mathrm{b}}$ & $10.51 \pm 0.14^{f}$ & $26.53 \pm 0.34^{c}$ & $17.10 \pm 0.25^{\mathrm{cd}}$ & $302.52 \pm 9.94^{f}$ & 30 & $0.56 \pm 0.007^{c}$ \\
\hline 270 & 30 & $5.60 \pm 0.08^{\mathrm{b}}$ & $11.03 \pm 0.14^{\mathrm{de}}$ & $27.51 \pm 0.34^{\mathrm{c}}$ & $17.94 \pm 0.25^{\mathrm{b}}$ & $338.07 \pm 9.90^{\mathrm{e}}$ & 30 & $0.58 \pm 0.007^{c}$ \\
\hline 300 & 30 & $5.48 \pm 0.08^{b}$ & $10.99 \pm 0.14^{\mathrm{e}}$ & $27.40 \pm 0.34^{c}$ & $17.93 \pm 0.24^{\mathrm{b}}$ & $335.51 \pm 10.08^{\mathrm{e}}$ & 29 & $0.57 \pm 0.007^{c}$ \\
\hline 330 & 30 & $5.48 \pm 0.08^{\mathrm{b}}$ & $11.08 \pm 0.15^{\mathrm{de}}$ & $27.23 \pm 0.35^{c}$ & $16.67 \pm 0.26^{\mathrm{d}}$ & $337.27 \pm 10.28^{\mathrm{e}}$ & 29 & $0.57 \pm 0.008^{\mathrm{c}}$ \\
\hline 360 & 30 & $4.98 \pm 0.08^{\text {de }}$ & $11.40 \pm 0.15^{\mathrm{cd}}$ & $27.39 \pm 0.35^{c}$ & $17.83 \pm 0.27^{\mathrm{b}}$ & $354.37 \pm 10.41^{\text {de }}$ & 29 & $0.57 \pm 0.008^{\mathrm{c}}$ \\
\hline 390 & 29 & $5.25 \pm 0.09^{c}$ & $11.77 \pm 0.16^{c}$ & $27.48 \pm 0.38^{\mathrm{bc}}$ & $16.59 \pm 0.28^{d}$ & $373.98 \pm 11.08^{\mathrm{d}}$ & 27 & $0.58 \pm 0.008^{c}$ \\
\hline 420 & 28 & $5.52 \pm 0.09^{b}$ & $12.44 \pm 0.16^{\mathrm{b}}$ & $28.36 \pm 0.39^{b}$ & $17.83 \pm 0.29^{\mathrm{bc}}$ & $433.05 \pm 11.32^{c}$ & 27 & $0.60 \pm 0.008^{\mathrm{b}}$ \\
\hline 450 & 28 & $5.61 \pm 0.09^{\mathrm{ab}}$ & $12.64 \pm 0.17^{\mathrm{ab}}$ & $29.31 \pm 0.40^{\mathrm{a}}$ & $19.35 \pm 0.30^{\mathrm{a}}$ & $479.98 \pm 11.73^{b}$ & 27 & $0.61 \pm 0.009^{\mathrm{ab}}$ \\
\hline 480 & 28 & $5.80 \pm 0.09^{\mathrm{a}}$ & $13.10 \pm 0.17^{\mathrm{a}}$ & $29.74 \pm 0.40^{\mathrm{a}}$ & $19.64 \pm 0.30^{\mathrm{a}}$ & $513.07 \pm 11.81^{a}$ & 27 & $0.62 \pm 0.009^{\mathrm{a}}$ \\
\hline \multicolumn{9}{|l|}{ Doğ. tipi } \\
\hline Tekiz & 288 & $4.96 \pm 0.03^{b}$ & $10.47 \pm 0.05$ & $25.45 \pm 0.11$ & $16.67 \pm 0.08$ & $314.77 \pm 3.31^{a}$ & 280 & $0.54 \pm 0.002^{\mathrm{a}}$ \\
\hline İkiz & 129 & $5.07 \pm 0.04^{\mathrm{a}}$ & $10.61 \pm 0.08$ & $25.81 \pm 0.18$ & $16.43 \pm 0.14$ & $340.31 \pm 5.41^{b}$ & 129 & $0.55 \pm 0.004^{b}$ \\
\hline \multicolumn{9}{|l|}{ Ana yaşı } \\
\hline 3 & 98 & $5.07 \pm 0.05$ & $10.90 \pm 0.09^{\mathrm{a}}$ & $25.79 \pm 0.21$ & $16.64 \pm 0.16$ & $348.30 \pm 6.31^{a}$ & 98 & $0.55 \pm 0.005$ \\
\hline 4 & 165 & $4.99 \pm 0.03$ & $10.16 \pm 0.06^{b}$ & $25.35 \pm 0.15$ & $16.53 \pm 0.11$ & $307.78 \pm 4.28^{b}$ & 157 & $0.54 \pm 0.003$ \\
\hline 5 & 154 & $4.98 \pm 0.04$ & $10.54 \pm 0.06^{c}$ & $25.75 \pm 0.15$ & $16.48 \pm 0.11$ & $326.55 \pm 4.39^{c}$ & 154 & $0.54 \pm 0.003$ \\
\hline Can. ağır. & & $0.042 \pm 0.003^{* *}$ & $0.072 \pm 0.005^{* *}$ & $0.175 \pm 0.01^{* *}$ & $0.122 \pm 0.008^{* *}$ & $6.037 \pm 0.33^{* *}$ & & - \\
\hline
\end{tabular}

$\mathrm{P}<0.01 ;{ }^{a, b, c, d, e, f, g, h, ı} \mathrm{P}<0.05$ : aynı sütunda ortalamalar arasındaki farklılıklar önemlidir. TÇ: testis çapı, TU: testis uzunluğu, SÇ: skrotum çevresi, SU: skrotum uzunluğu, TH: testis hacmi 
Çizelge 2. Norduz erkek kuzularında çift testis ağırlığı, çift epididimis ağırlığı ve skrotum ağırlığına ilişkin en küçük kareler ortalamaları

\begin{tabular}{|c|c|c|c|c|}
\hline & & Çift testis ağır. (kg) & Çift epid.ağır. (kg) & Skr.ağır. (kg) \\
\hline Sınıflama & $\mathrm{n}$ & $\bar{X} \pm S_{\bar{X}}$ & $\bar{X} \pm S_{\bar{X}}$ & $\bar{X} \pm S_{\bar{X}}$ \\
\hline Genel & 21 & $0.319 \pm 0.02$ & $0.051 \pm 0.006$ & $0.223 \pm 0.02$ \\
\hline \multicolumn{5}{|l|}{ Doğum tipi } \\
\hline $\begin{array}{c}\text { Tekiz } \\
\text { ikiz }\end{array}$ & $\begin{array}{c}12 \\
9\end{array}$ & $\begin{array}{l}0.298 \pm 0.02 \\
0.348 \pm 0.03\end{array}$ & $\begin{array}{l}0.055 \pm 0.005 \\
0.046 \pm 0.007\end{array}$ & $\begin{array}{l}0.194 \pm 0.02 \\
0.261 \pm 0.03\end{array}$ \\
\hline \multicolumn{5}{|l|}{ Ana yaşı } \\
\hline $\begin{array}{l}3 \\
4 \\
5\end{array}$ & $\begin{array}{l}5 \\
7 \\
9\end{array}$ & $\begin{array}{l}0.340 \pm 0.03 \\
0.290 \pm 0.02 \\
0.340 \pm 0.02\end{array}$ & $\begin{array}{l}0.051 \pm 0.009 \\
0.049 \pm 0.006 \\
0.050 \pm 0.006\end{array}$ & $\begin{array}{l}0.250 \pm 0.04 \\
0.184 \pm 0.03 \\
0.248 \pm 0.02\end{array}$ \\
\hline Regresyon & & & & \\
\hline Canlı ağırlık & & $0.00193 \pm 0.001$ & $-0.0001 \pm 0.0003$ & $0.0036 \pm 0.001^{*}$ \\
\hline
\end{tabular}

Norduz kuzularında çift testis ağırlığı, çift epididimis ağırlığı ve skrotum ağırlığına ilişkin en küçük kareler ortalamaları Çizelge 2'de verilmiştir. Norduz erkek kuzularında çift testis ağırlığı, çift epididimis ağırlığı skrotum ağırlığına ilişkin en küçük kareler ortalamaları sırasıyla $0.319 \pm 0.02, \quad 0.051 \pm 0.006$ ve $0.223 \pm 0.02 \mathrm{~g}$ olarak saptanmıştır. Söz konusu özellikler bakımından doğum tipi ve ana yaşı grupları arasında istatistik olarak önemli bir fark saptanmamıştır. Çift testis ağırığı ve çift epididimis ağırlığı üzerine canlı ağırlığın etkisi önemsiz, skrotum ağırlığı üzerine etkisinin ise önemli $(P<0.05)$ olduğu bulunmuştur.

Norduz erkek kuzularında serum testosteron konsantrasyonu: Norduz erkek kuzularında testosteron konsantrasyonuna ilişkin en küçük kareler ortalamaları Çizelge 3'de verilmiştir. Buna göre Norduz erkek kuzularında testosteron konsantrasyonuna ilişkin en küçük kareler ortalamasının $2.42 \pm 0.12 \mathrm{ng} / \mathrm{ml}$ olduğu görülmüştür. Çizelge 3'de serum testosteron konsantrasyonunun 120, 210, 240 ve 450 günlük yaş dönemlerinde yüksek olduğu ancak değerler arasında istatistik olarak farkılık bulunmadığı görülmektedir. Yaş dönemleri arasında istatistik olarak önemli bir farklılık olmadığı saptanmıştır. Çizelge 3'de 270 günlük yaş döneminde serum testosteron konsantrasyonunda önemli $(P<0.01)$ bir düşüş olduğu gözlenmektedir. Aynı şekilde serum testosteron konsantrasyonu üzerine canlı ağırlığın $\mathrm{P}<0.01$ düzeyinde etkisinin çok önemli, doğum tipi ve ana yaşının etkisinin ise istatistik olarak önemli olmadığı saptanmıştır.

Çizelge 3. Norduz erkek kuzularında testosteron konsantrasyonuna ilişkin en küçük kareler ortalamaları

\begin{tabular}{|c|c|c|}
\hline & \multicolumn{2}{|c|}{ Testosteron konsantrasyonu (ng/ml) } \\
\hline Sınıflama & $\mathrm{N}$ & $\bar{X} \pm S_{\bar{X}}$ \\
\hline Genel & 382 & $2.42 \pm 0.12$ \\
\hline Yaş dönemleri (gün) & & \\
\hline $\begin{array}{c}90 \\
120 \\
150 \\
180 \\
210 \\
240 \\
270 \\
300 \\
330 \\
360 \\
390 \\
420 \\
450 \\
480 \\
\end{array}$ & $\begin{array}{l}26 \\
23 \\
25 \\
30 \\
31 \\
32 \\
32 \\
32 \\
32 \\
29 \\
32 \\
22 \\
13 \\
23\end{array}$ & $\begin{array}{l}2.45 \pm 0.15^{\text {bcde }} \\
2.91 \pm 0.15^{\mathrm{a}} \\
2.37 \pm 0.13^{\text {dge }} \\
2.54 \pm 0.12^{\text {bcd }} \\
2.69 \pm 0.11^{\text {abc }} \\
2.61 \pm 0.11^{\text {abcd }} \\
1.85 \pm 0.11^{\mathrm{g}} \\
2.11 \pm 0.11^{\text {def }} \\
2.43 \pm 0.11^{\text {def }} \\
2.51 \pm 0.12^{\text {bcd }} \\
2.35 \pm 0.12^{\text {def }} \\
2.17 \pm 0.14^{\text {def }} \\
2.85 \pm 0.18^{\text {ab }} \\
2.29 \pm 0.14^{\text {dge }}\end{array}$ \\
\hline Doğum tipi & & \\
\hline $\begin{array}{c}\text { Tekiz } \\
\text { Ikiz }\end{array}$ & $\begin{array}{l}267 \\
115\end{array}$ & $\begin{array}{l}2.39 \pm 0.04 \\
2.43 \pm 0.06\end{array}$ \\
\hline Ana yaşı & & \\
\hline $\begin{array}{l}33 \\
4 \\
5\end{array}$ & $\begin{array}{c}85 \\
168 \\
129\end{array}$ & $\begin{array}{l}2.41 \pm 0.07 \\
2.48 \pm 0.05 \\
2.42 \pm 0.05\end{array}$ \\
\hline $\begin{array}{l}\text { Regresyon (linear) } \\
\text { Canlı ağırlık }\end{array}$ & & $0.014 \pm 0.004^{* *}$ \\
\hline
\end{tabular}



yaşa göre değişimi"

\section{Tartışma}

Norduz erkek kuzularında testis çapı $4.99 \mathrm{~cm}$ olup saptanan bu değer Aygün ve Karaca'nın (1995 ve 2000) Karakaş kuzularında saptadığı $2.87 \mathrm{~cm}$ ve 2.60 cm; Yılmaz ve Aygün'ün (2002) Norduz kuzularında bildirdiği 3.18 cm; Öztürk ve ark.'nın (1995b) Konya Merinosu toklularında buldukları $2.41 \mathrm{~cm}$; Kaymakçı ve ark.'nın (1988) Acıpayam kuzularında belirlediği 3.85 cm; Odabaşıŏlu ve ark.'nın (1992) Morkaraman toklularında bildirdiği $3.65 \mathrm{~cm}$ değerinden yüksek; Taşkın ve Kaymakçı'nın (1996) Kıvırcık ve Dağlıç kuzularında bildirdiği $8.87 \mathrm{~cm}$ ve $7.15 \mathrm{~cm}$; Öztürk ve ark.'nın (1996) İvesi toklularında bildirdiği 5.86 değerinden düşük; Gündoğan ve ark.'nın (1999) Karayaka toklularında bildirdiği $4.75 \mathrm{~cm}$ değerine benzer bulunmuştur. Norduz kuzularında testis uzunluğu $10.47 \mathrm{~cm}$ olup saptanan bu değer Aygün ve Karaca'nın (1995 ve 2000) Karakaş kuzularından bildirdiği 5.33 ve $5.21 \mathrm{~cm}$; Yılmaz ve Aygün'ün (2002) Norduz kuzularında bildirdiği $6.26 \mathrm{~cm}$; Öztürk ve ark.'nın (1995b) Konya Merinosu toklularında belirlediği 5.70 cm; Kaymakçı ve ark.'nın (1988) Acıpayam kuzularında saptadığı $6.02 \mathrm{~cm}$; Odabaşıoğlu ve ark.'nın (1992) Morkaraman erkek toklularında bildirdiği 7.38 cm; Taşkın ve Kaymakçı'nın (1996) Kıvırcık ve Dağlıç kuzularında saptadığı $9.45 \mathrm{~cm}$ ve $7.25 \mathrm{~cm}$ değerlerinden yüksek bulunmuştur. Öztürk ve ark.'nın (1996) İvesi erkek toklularında bulduğu 11.95 cm değerine benzer; Gündoğan ve ark.'nın (1999) Karayaka erkek toklularında bildirdiği $14.4 \mathrm{~cm}$ değerinden ise düşük bulunmuştur.

Çalışmada etkisi incelenen çevre faktörlerinden doğum tipinin testis çapı üzerine etkisi önemli $(P<0.05)$ bulunmuştur. Buna karşılık ana yaşının testis çapı üzerine etkisi istatistik olarak önemli bulunmamıştır. Testis uzunluğu bakımından da tekiz ve ikiz kuzular arasında istatistik olarak önemli bir farklılık saptanmamıştır. Buna karşılık testis uzunluğu üzerine ana yaşının önemli $(P<0.01)$ etkisi olduğu gözlenmiştir. Üç yaşlı anaların kuzularının daha yüksek testis uzunluğuna sahip olduğu gözlenmiştir. Kaymakçı ve ark., (1988) Acıpayam kuzularında testis çapı ve testis uzunluğunun ana yaşı ve doğum tipinden etkilenmediğini bildirmişlerdir. Yılmaz ve Aygün (2002), Norduz kuzularında testis çapı ve testis uzunluğu üzerine doğum tipi ve ana yaşı etkisinin testis özelliğine göre değiştiğini bildirmişlerdir. Buna göre testis çapı üzerine doğum tipi ve ana yaşının etkisi önemsiz, testis uzunluğunun ise doğum tipinden etkilendiği bildirilmiştir $(P<0.05)$. Aynı şekilde, Matos ve ark. (1992) doğum tipinin testis özelliklerine etkisinin 90 günlük yaşa kadar devam ettiğini ve yaşa bağlı olarak bu etkinin azaldığını bildirmişlerdir.
Norduz erkek kuzularında skrotum çevresi 25.51 cm olup saptanan bu değer Aygün ve Karaca'nın (1995; 2000) Karakaş kuzularında belirlediği $14.62 \mathrm{~cm}$ ve $18.02 \mathrm{~cm}$; Yılmaz ve Aygün'ün (2002) Norduz kuzularında gözlediği $17.44 \mathrm{~cm}$; Öztürk ve ark.'nın (1995b) Konya Merinosu erkek toklularında saptadığı 18.67 cm; Kaymakçı ve ark.'nın (1988) Acıpayam kuzularında gözlediği $21.97 \mathrm{~cm}$; Odabaşıŏlu ve ark.'nın (1992) Morkaraman ırkı için saptadığı 21.52 $\mathrm{cm}$ değerlerinden yüksek bulunmuştur. Buna karşılık Taşkın ve Kaymakçı'nın (1996) Kıvırcık ve Dağlıç kuzularında bildirdiği $35.92 \mathrm{~cm}$ ve $33.81 \mathrm{~cm}$; Öztürk ve ark.'nın (1996) İvesi toklularında saptadığı $31.70 \mathrm{~cm}$; Gündoğan ve ark.'nın (1999) Karayaka toklularında bildirdiği $29.10 \mathrm{~cm}$ değerlerinden düşük bulunmuştur. Norduz erkek kuzularında skrotum uzunluğu $16.28 \mathrm{~cm}$ olup saptanan bu değer Aygün ve Karaca'nın (1995; 2000) Karakaş kuzularında bildirdiği $9.27 \mathrm{~cm}$ ve 8.31 $\mathrm{cm}$; Yılmaz ve Aygün'ün (2002) Norduz kuzularında gözlediği 11.76 cm; Kaymakçı ve ark.'nın (1988) Acıpayam kuzularında belirlediği $9.67 \mathrm{~cm}$; Odabaşıoğlu ve ark.'nın (1992) Morkaraman toklularında saptadığı $10.20 \mathrm{~cm}$; Öztürk ve ark.'nın (1995b) Konya Merinosu erkek toklularında bildirdiği $12.33 \mathrm{~cm}$ değerlerinden yüksek bulunmuştur. Buna karşılık Taşkın ve Kaymakçı'nın (1996) Kıvırcık erkek kuzularında bildirdiği $19.21 \mathrm{~cm}$; Gündoğan ve ark.'nın (1999) Karayaka toklularında belirlediği $18.70 \mathrm{~cm}$ değerlerinden düşük bulunmuştur. Skrotum uzunluğu için saptanan değer Taşkın ve Kaymakçı'nın (1996) Dağlıç kuzularında bulduğu $16.69 \mathrm{~cm}$; Öztürk ve ark.'nın (1996) İvesi tokluları için saptadığı $17.63 \mathrm{~cm}$ değerlerine benzer bulunmuştur.

Skrotum çevresi ve skrotum uzunluğu üzerine etkisi incelenen kesikli çevre faktörlerinden doğum tipi ve ana yaşının etkisi istatistik olarak önemli bulunmamıştır. Bir başka çalışmada da (Kaymakçı ve ark., 1988) söz konusu kesikli çevre faktörlerinin skrotum çevresi ve skrotum uzunluğunu önemli ölçüde etkilemediği ortaya koyulmuştur. Buna karşılık Yılmaz ve Aygün (2002), Norduz erkek kuzularında skrotum çevresinin ana yaşından etkilendiğini bildirmişlerdir $(\mathrm{P}<0.05)$.

Testis çapı, testis uzunluğu, skrotum çevresi ve skrotum uzunluğu üzerine canlı ağırlığın ve yaş dönemlerinin önemli etkide bulunduğu saptanmıştır. Canlı ağırlık ve yaşa bağlı olarak skrotum çevresi ve skrotum uzunluğunda gözlenen önemli farklılık kimi çalışmalarda da (Aygün ve Karaca 1995, Öztürk ve ark. 1995a,b, Taşkın ve Kaymakçı 1996, Aygün ve Karaca 2000, Yılmaz ve Aygün 2002) ortaya koyulmuştur. 
Norduz kuzularında testis hacmi $324.05 \mathrm{~cm}^{3}$ olup saptanan bu değer Elmaz'ın (2002) 420 günlük yaştaki Kıvırcık erkek kuzuları için bildirdiği $454.7 \mathrm{~cm}^{3}$; Emsen'in (2005) 360 günlük yaşlı İvesi, Morkaraman, Morkaramanxivesi ve İvesixMorkaraman melezi kuzuları için saptadığı $39.8,42.4,44.7,44.7 \mathrm{ml}$ değerlerinden düşük bulunmuştur. Norduz kuzularında saptanan bu değer Avdi ve ark.'nın (2004) 2.5 yaşlı Sakız ve Serres koçları için bildirilen 146.04 ve 138.71 $\mathrm{ml}$ değerlerinden yüksek bulunmuştur.

Norduz kuzularında skrotum çevresi/canlı ağırlık oranı 0.54 olup saptanan bu değer Suffolk, St. Croix, Finn ve Hampshire ırkları için sırasıyla bildirilen 0.66 , $0.80,0.87$ ve 0.76 değerlerinden düşük bulunmuştur. Buna karşılık, Rambouillet ırkı için bildirilen 0.59 değerine benzer bulunmuştur. Testis hacmi ve skrotum çevresi/canlı ağılık oranı üzerine canlı ağırlığın, yaş dönemlerinin ve doğum tipinin etkisi önemli bulunmuştur $(P<0.05-P<0.01)$.

Norduz kuzularında çift testis ağırlığı, çift epididimis ağırlığı ve skrotum ağırlığına ilişkin değerler sırasıyla 319, 51 ve $223 \mathrm{~g}$ olarak bulunmuştur. Çift testis ağırlığı için saptanan bu değer Romanov kuzularında imunnokastrasyonun üreme özellikleri ve karkas özelliklerine etkisinin araştırıldığı bir çalışmada (Fahmy ve ark. 1999) kontrol grubu için saptanan 204 g; Karakaş kuzularında iki farklı kastrasyon uygulamasının üreme ve karkas özellikleri üzerine etkisinin araştırıldığı bir çalışmada (Ülker ve ark. 2002) kontrol grubu için bildirilen $269 \mathrm{~g}$ değerlerinden yüksek; Brown ve ark.'nın (1994) GnRH'ya karşı immunize edilen 115 günlük yaştaki Merinos ırkı kuzularında kontrol grubu için saptanan $338 \mathrm{~g}$ değerine benzer bulunmuştur.

Testis özelliklerinde kimi yaş dönemlerinde gözlemlenen düşüş, ölçüm dönemlerindeki düşük ortalama sıcaklıktan kaynaklandığı düşünülmektedir. Nitekim Suffolk ve DLS (1/2 Dorset, $1 / 4$ Leicester ve $1 / 4$ Suffolk) koçlarında üreme özelliklerinin mevsimsel değişiminin araştırıldığı bir çalışmada (Dufour ve ark 1984) testis çapının Mart-Mayıs ayları arasında önemli bir düşüş gösterdiği ancak Haziran ayından itibaren artmaya başladığı ve Ekim ayında en yüksek değere ulaştığı bildirilmiştir. Soay koçlarında da (Lincoln ve ark. 1990) testis çapının mevsimden etkilendiği saptanmıştır. Yine Aygün ve Yılmaz (2003) Norduz erkek oğlaklarında da kimi testis özelliklerinin mevsimsel değişimler gösterdiğini ve özellikle skrotum uzunluğunun düşük ortalama sıcaklıktan etkilendiğini gözlemişledir.

Norduz erkek kuzularında serum testosteron konsantrasyonu: Norduz erkek kuzularında testosteron konsantrasyonu $2.42 \mathrm{ng} / \mathrm{ml}$ olarak bulunmuştur. Saptanan bu değer Gonzalez ve ark.'nın (1988) Ile-de-France ırkı için bildirdiği $13.40 \mathrm{ng} / \mathrm{ml}$; Langford ve ark.'nın (1998) Canadian, Finnish Landrace, Outaouais, Rideau ırkları için sırasıyla saptadıkları 3.50, 7.80, $5.40 \mathrm{ng} / \mathrm{ml}$; Gündoğan ve ark.'nın (1999) Akkaraman ırkı için bildirdiği 6.03 ng/ml; Lincoln ve ark.'nın (1990) Blackface, Herdwick, Muflon, Norfolk, Portland, Shetland, Soay, SoayxMerinos, SoayxPortland, Wildshire ırkları için sırasıyla gözledikleri 6.98, 8.16, 4.48, 7.72, 6.58, 8.86, 7.38, 5.78, 7.05, 8.04 ng/ml; Kaya ve ark.'nın (1999) Konya Merinosu için saptadığı $5.10 \mathrm{ng} / \mathrm{ml}$; Kafi ve ark.'nın (2004) Karagül ırkı için belirdiği $6.00 \mathrm{ng} / \mathrm{ml}$ değerlerinden düşük; Lincoln ve ark.'nın (1990) Merinos ırkı için saptadığı 2.57 ng/ml; Elmaz'ın (2002) Kıvırcık kuzuları için bildirdiği $2.74 \mathrm{ng} / \mathrm{ml}$ değerlerine benzer bulunmuştur.

Çalışmamızda testosteron konsantrasyonu üzerine ana yaşı ve doğum tipinin etkisi önemsiz, yaş dönemleri ve canlı ağırlığın etkisinin ise istatistik olarak önemli olduğu gözlenmiştir. Özellikle testosteron konsantrasyonunun yaş dönemlerine göre değişiminin düzenli olmadığı gözlenmiştir. Kuşkusuz böyle bir durumun ortaya çıkması başta mevsim olmak üzere çok çeşitli faktörlerden kaynaklanmaktadır (Lincoln ve ark. 1990, Langford ve ark. 1998). Testosteron değerlerinin normal dağılım göstermemesi ve transformasyona tabi tutulması bunda etkili olabilmektedir. Yine testosteron analizinde kullanılan (RIA) tekniği ve kitler de bunda rol oynayabilmektedir (Güven ve ark. 2003). Serum testosteron konsantrasyonunda 270 günlük yaş döneminde meydana gelen düşüş mevsimden kaynaklanmış olabilir. Koçlarda serum testosteron konsantrasyonunda görülen mevsimsel dalgalanmalar başka çalışmalarda da gözlemlenmiştir (Lincoln ve ark. 1977, Lincoln ve ark. 1990).

Testosteron konsantrasyonu üzerine etkisi incelenen çevre faktörlerinden ana yaşı ve doğum tipinin etkisi istatistik olarak önemsiz, canlı ağılık ve yaş dönemlerinin etkisi ise önemli bulunmuştur $(P<0.05-P<0.01)$. Canlı ağırlık ve yaş dönemlerinin testosteron konsantrasyonu üzerine önemli etkisi Langford ve ark. (1998), Aygün ve Karaca (2000) ve Elmaz (2002) tarafından da bildirilmektedir.

\section{Sonuç}

Sonuç olarak, Norduz erkek kuzularında üreme özelliklerinin yaş dönemlerine göre değişimi üreme özelliğine göre farklılık göstermektedir. Özellikle testosteron konsantrasyonunun yaş dönemleri içindeki değişiminin son derece düzensiz olduğu gözlenmiştir. $\mathrm{Bu}$ durum başta hormon analiz tekniği (RIA) olmak 

yaşa göre değişimi"

üzere çok çeşitli faktörlerin etkisinden kaynaklanmış olabilir. Genel olarak koç seleksiyon programlarında testis özellikleri ve testosteron konsantrasyonu önemli olmakla birlikte sperma ve cinsel davranış özellikleriyle birlikte kombinasyonlarından daha etkili sonuçlar alınabileceği anlaşılmaktadır.

\section{Kaynaklar}

Avdi, M., G. Banos, K. Stefos ve P. Chemineau. 2004. Seasonal variation in testicular volume and sexual behavior of Chios and Serres rams. Theriogenology 62 : 275-282.

Aygün, T. ve O. Karaca. 1995. Karakaş erkek kuzularında kimi testis özellikleri. Tr. J. Vet.Anim.Sci. 19: 161-167.

Aygün, T. ve O. Karaca. 2000. Karakaş erkek kuzularında serum testosteron konsantrasyonları ile testis özellikleri arasındaki ilişkiler. Ankara Üniv. Zir. Fak. Tar. Bil. Derg 6 (3): 97-101.

Aygün, T. ve A. Yılmaz. 2003. Norduz erkek oğlaklarında bazı testis özellikleri J Vet. Anim. Sci, 27: 1441-1445.

Bingöl, M. 1998. Norduz Koyunlarının Döl ve Süt Verimi ile Büyüme-gelişme ve Dış yapı Özellikleri (doktora tezi, basılmamış, 97s). Yüzüncü Yıl Üniv. Fen.Bil. Enst. Van.

Brown, B.W., P.E. Mattner, P. A. Carroll, E. J. Holland, D. R. Paul, R. M. Hoskinson and R. D. G. Rigby. 1994 Immunization of sheep against $\mathrm{GnRH}$ early in life: effects on reproductive function and hormones in rams. J. Reprod. Fert. 101: 15-21.

Elmaz, Ö. 2002. Kıvırcık Erkek Kuzuların Damızlıkta Erken Kullanılma Yaşının Belirlenmesi Üzerine Araştırmalar İstanbul Üniversitesi Sağlık Bil. Enst., Doktora Tezi, basılmamış, 80s, İstanbul.

Emsen, E. 2005. Testicular development and body weight gain from birth to 1 year of age of Awassi and Redkaraman sheep and their reciprocal crosses. Small Rumin. Res. 59: 79-82.

Fahmy, M.H., M. R. Sairam, J. G. Proulx, H. V. Petit, L. G. Jiang and J. J. Dufour. 1999. Effect of active immunization against luteinizing hormone on carcass and meat quality of Romanov lambs. Small Rumin. Res. 34: $87-96$

Fernandez, M., F. J. Ginaldez, P. Frutos, P. Lavin and A. R. Mantecon. 2004. Effect of undegradable protein supply on testicular size, spermiogram parameters and sexual behavior of mature Assaf rams. Theriogenology 62 (1-2): 299-310.

Godfrey, R.W., J. R. Collins and M. L. Gray. 1998. Evaluation of sexual behaviour of hair sheep rams in a tropical environment. J. Anim. Sci. 76: 714-717.

Gonzalez, R., P. Poindron and J. P. Signoret. 1988. Temporal variation in $\mathrm{LH}$ and testosterone responses of rams after the introduction of oestrous females during the breeding season. J.Reprod. Fert. 83: 201-208.
Gündoğan, M. 1999. Koçların testis ölçülerinin spermatolojik özellikleri ve kan serumu testosteron miktarları ile ilişkisi. Hay. Araş. Derg. 9(1-2): 49-52.

Gündoğan, M., M. Uçar, ve M. Tekerli. 2002. Afyon koşullarında yetiştirilen koçlarda testislerin morfometrik ölçümleri ve spermatolojik özellikleri üzerinde araştırmalar. Vet. Bil. Derg. 18(1-2): 63-67.

Gündoğan, M., M. Uçar, M. Tekerli and D. Yeni. 2003. Possible association between age and reproductive parameters in Akkaraman rams during breeding season. Hay. Araş. Derg. 13:1-2.

Güven, B., S. Özsar, N. Maraşlı, Ş. Maraşlı ve A. Özcan. 2003. Testosteron için enzimimmunoassay tekniğinin geliştirilmesi. Türk.J.Vet.Anim.Sci. 20:45-50.

Kafi, M., M. Safdarian and M. Hashemi. 2004. Seasonal variation in semen characteristics, scrotal circumference and libido of Persian Karakul rams. Small Rumin. Res. 53 (1-2): 133-139.

Kaya, A., C. Yıldız, N. C. Lehimcioğlu, A. Ergin ve M. Aksoy. 1999. Konya Merinosu koçlarında sperma kalitesi, testis ölçüleri ve kan testosteron düzeylerine ilişkin mevsimsel değişikliklerin araştııılması. Hay. Araş. Derg. 9 (1-2): 1-5.

Kaymakçı, M., C. Sarıcan ve O. Karaca. 1988. Acıpayam erkek kuzularında testis özellikleri üzerinde araştırmalar. Ege Üniv. Zir. Fakt. Derg. 25 (2): 109-123.

Langford, G. A., J. N. B. Shrestha, L. M. Sanford and G. J. Marcus. 1998. Reproductive hormone levels of early postpubertal ram lambs in relation to breed, adult testis size and semen quality. Small. Rumin. Res. 29: 225-231.

Lincoln, G.A., M. J. Peet and R. A. Cunningham. 1977. Seasonal and circadian changes in the episodic release of follicle-stimulating hormon, luteinizing hormone and testosterone in rams exposed to artificial photoperiods. J.Endoc. 72: 334-349.

Lincoln, G. A., C. E. Lincoln and A. S. McNeilly. 1990. Seasonal cycles in the blood plasma concentration of fsh, Inhibin and testosterone, and testicular size in rams of wild, feral and domesticated breeds of sheep. J.Reprod.Fert. 88: 623-633.

Matos, C. A. P., D. L. Thoma, T. G. Nash, D. F. Waldron and J. M. Stookey. 1992. Genetic analyses of scrotal circumference size and growth in Rambouillet lambs. J. Anim. Sci. 70:43-50.

Odabaşıoğlu, F., O. Karaca ve T. Altın. 1992. Morkaraman toklu ve koçlarının bazı testis özellikleri. Selçuk Üniv. Zir. Fakt. Derg. 8 (1): 32-33.

Öztürk, A., B. Dağ ve U. Zülkadir. 1995a. Akkaraman toklularında canlı ağılık, skrotum çevresi ve testis hacmi arasındaki ilişkiler. Selçuk Üniv. Zir. Fak. Derg. 7(9):218219 
Öztürk, A., B. Dağ, U. Zülkadir ve A. H. Aktaş. 1995b. Konya Merinosu toklu ve koçlarının bazı testis özellikleri. Hay. Araş. Derg. 5:1-2.

Öztürk, A., B. Dağ ve U. Zülkadir. 1996. Akkaraman ve İvesi koçlarının bazı testis özelliklerinin döl verimine etkisi. $\mathrm{Tr}$. J. Vet. Anim. Sci. 20: 127-130.

Sanford, L. M., C. Moore, J. K. Voglmayr. and M. H. Fahmy. 2000. Sexual maturational changes in circulatory inhibin concentration in relation to $\mathrm{FSH}$ concentration and testicular size in Suffolk and DLS (1/2 Dorset, $1 / 4$ Leicester, $1 / 4$ Suffolk) rams. Theriogenology 54: 719730 .

S.A.S. 2005. User's Guide: Statistics. SAS Inst. Inc., Cary, NC.

Taşkın, T. ve M. Kaymakçı. 1996. Kıvırcık ve Dağlıç erkek kuzularında kimi üreme özelliklerinin değişimi. Ege Üniv. Ziraat. Fak. Derg. 33 (2-3): 73-81.
Sönmez, R. ve M. Kaymakçı. 1987. Koyunlarda Döl verimi. s: 350. Ege Üniv. Zir. Fak. Yay. No. 404, İzmir,

Ülker, H., Ö. Gökdal, C. Temur, C. Budağ, M. Oto, D. M. deAvila and J. J. Reeves. 2002. The effect of immunization against LHRH on body growth and carcass characteristics in Karakaş ram lambs. Small Rumin. Res. 45: $273-278$

Yılmaz, A. ve T. Aygün. 2002. Norduz erkek kuzularının bazı testis özellikleri. Yüzüncü Yı Üniv. Zir. Fak. Tarım Bil. Derg. 1(12): 21-26

Iletişim Adresi:

Ayhan YILMAZ

Yüzüncü Yıl Üniv. Ziraat Fak. Zootekni Bölümü- Van 
